\title{
The tectonics and stratigraphy of the transitional zone between the Pieniny Klippen Belt and Magura Nappe (Szczawnica area, Poland)
}

\author{
Edyta Jurewicz, Tomasz Segit \\ University of Warsaw, Institute of Basic Geology; ul. Żwirki i Wigury 93, 02-089 Warsaw, Poland; \\ e-mail:edyta.jurewicz@uw.edu.pl,t.segit@uw.edu.pl
}

\begin{abstract}
(C) 2018 Authors. This is an open access publication, which can be used, distributed and reproduced in any medium according
\end{abstract} to the Creative Commons CC-BY 4.0 License requiring that the original work has been properly cited.

Received: 29 January 2018; accepted: 16 February 2018

\begin{abstract}
The Pieniny Klippen Belt is a narrow, complex structure stretching along a tectonic boundary between the Central and Outer Carpathians. Its formation involved two main evolutionary stages, the first, related to Late Cretaceous-Paleocene folding and thrusting, and the second, associated with Miocene orogenic events in the Outer Carpathians. Interactions between the Pieniny Klippen Belt and Outer Carpathians during both the sedimentation and deformation stages have resulted in the establishment of a peri-klippen transitional zone (named the Šariš Transitional Zone), in which the tectonic deformation effects gradually decrease towards the north. The stratigraphy and tectonic position of this zone have been controversial for decades. The key stratigraphic problems concern 1) the lithologic identity and position of the Szlachtowa ("black flysch"), Opaleniec and Pieniny formations and 2) the relation of the Jarmuta Formation, associated mainly with the Šariš Transitional Zone, to the Szczawnica and Zarzecze formations of the Magura Nappe. We provide an early Paleogene dinoflagellate cyst stratigraphic record of deposits that, according to some recent reinterpretations, represent the Neogene "Kremna Formation". The legitimacy of new lithostratigraphic assignments of the "Kremna Formation" at Jaworki is put into question upon the basis of the primacy of units introduced for the same strata earlier.
\end{abstract}

Keywords: olistoliths, gravitational slumping, Šariš Transitional Zone, dinoflagellate cyst stratigraphy, Grajcarek Succession, Kremna Formation

\section{TECTONIC EVOLUTION OF THE PIENINY KLIPPEN BELT}

The Pieniny Klippen Belt (PKB) represents a ca. $600-700 \mathrm{~km}$ long trace of a major suture located between the Central and Outer Carpathians (Figs. 1, 2). It involves Jurassic (locally Triassic) to Paleogene deposits of very variable lithology (e.g. Andrusov 1965, Birkenmajer 1986, Plašienka et al. 2012). In the Polish/Slovakian borderland, the structure of the PKB includes the so called Klippen tectonostratigaphic units of Czorsztyn, Niedzica, Czertezik, Branisko, Pieniny and Haligovce (e.g. Birkenmajer 1986, Mišík 1997). In the lithostratigraphical sense, the PKB sedimentary sequences can be divided into two main complexes: a "rigid" carbonate rocks - dominated complex of Middle Jurassic-Late Cretaceous age, and a ductile complex of shales, marls and flysch rocks of Late Cretaceous age. The third rock complex, in most cases less significant than the other two because of its smaller thickness, consists of ductile Lower-to-Middle Jurassic marls, shales and mudstones. This contrasting lithology of sedimentary sequences was responsible for the PKB disintegration into isolated klippen during a complex tectonic evolution (Birkenmajer 1959). 


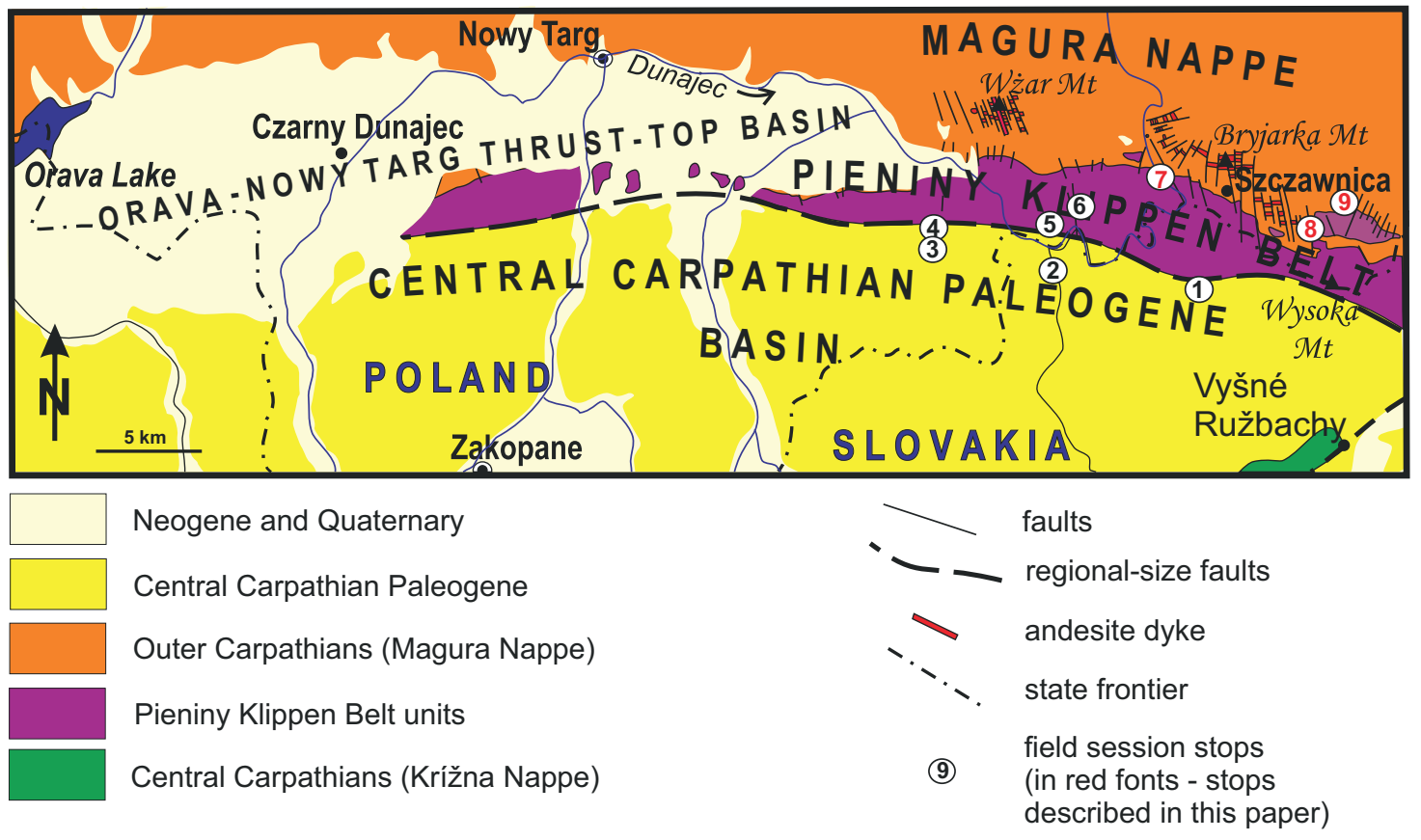

Fig. 1. Approximate location of field session stops on a generalized geological map showing the tectonic setting of the Pieniny Klippen Belt in Poland (based on Birkenmajer 1979 and Jurewicz 2005, simplified)

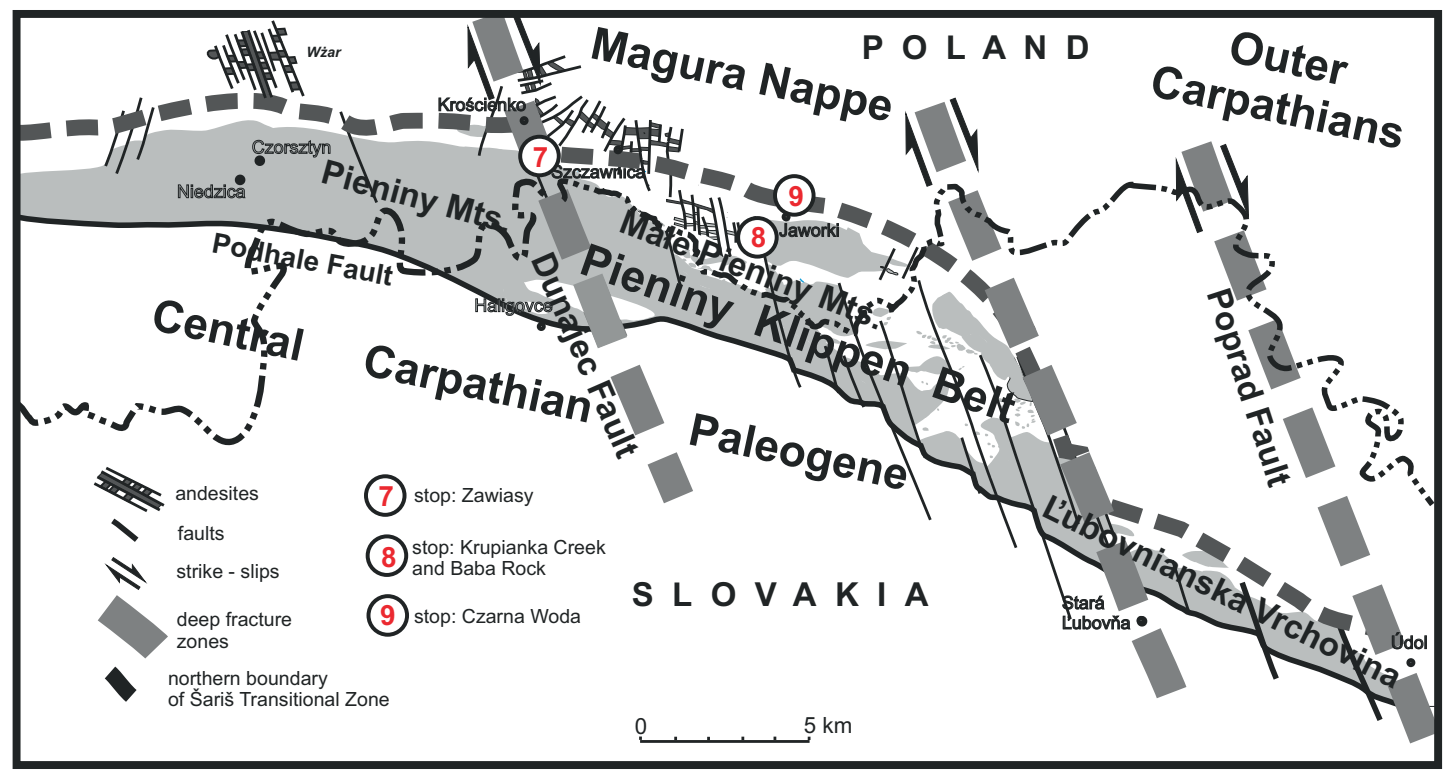

Fig. 2. Geological sketch-map of the Pieniny Klippen Belt in the vicinity of the Polish/Slovakian frontier (based on Birkenmajer 1979, Jurewicz 1994, 2018, Plašienka 2012, simplified and modified)

During the deposition of the PKB sedimentary succession, a separate Grajcarek Basin was located to the north. Both the basins have been isolated by the Czorsztyn Ridge since the latest Aalenian-Early Bajocian. From the Albian onward, the Grajcarek Basin lost its individuality and became part of the Magura depositional basin. The recent structure of the PKB developed in two main stages of tectonic evolution (e.g. Froitzheim et al. 2008). The first stage was related to Late Cretaceous-Paleocene folding and thrusting. Simultaneously with the folding events, in the Magura Basin located to the north, the so called Jarmuta Fm. originated, composed mainly of wildflysch sediments, 
containing clasts of the klippen rocks (Birkenmajer 1970). Due to a favorable paleotopography, the northernmost tectonostratigraphic units of the PKB (the Czorsztyn and Niedzica units) were transported through gravity sliding, defragmented into slices and thrust onto sediments of the Magura Basin, forming numerous olistoliths and olistostromes (Jurewicz 1994, 1997, Plašienka et al. 2017). One of the largest olistoliths can be observed in the Małe Pieniny. It defines the Homole-Biała Woda Block, composed of the flat-laying Czorsztyn Unit and of the thrust-faulted and strongly folded Niedzica Unit. The Biała Woda Block has gravitationally slid onto sediments which used to be considered part of the so called Grajcarek Unit by Birkenmajer (1970). According to Birkenmajer (1970), the Grajcarek Unit was back-thrust to the south over the nappes of the Klippen Belt, to later form tectonic remnants. Plašienka (2012), in turn, called this unit the Šariš Unit which - in his opinion - formed the tectonically lowermost tectonic body of the PKB. This unit was interpreted by this author as having formed due to repeated gravity sliding which episodically continued until the early Eocene. However, both the Grajcarek Unit in Poland (Birkenmajer 1979, 1986) and the Šariš Unit in Slovakia (Plašienka et al. 2012) do not fulfill the necessary criteria to constitute a separate tectonic unit, since representing such a unit would require: (1) coherent tectonosedimentary evolution, (2) a precise timing of its tectonic deformation and (3) an unambiguous definition of its borders (Jurewicz 2018). Instead of defining the Grajcarek or Šariš Unit, it is a better idea to distinguish a transitional zone at the Magura-directed front of the Klippen Belt, and to name it the Šariš Transitional Zone. The latter must have originated due to polygenetic and polyphase tectono-sedimentary processes. Such a transitional zone does not require a northern limit, which is also expected to separate the Central from the Outer Carpathians and which is difficult to be found in the field.

During the Paleocene-Eocene Thermal Maximum (Storey et al. 2007) and global sea-level changes, the PKB collapsed and was buried under a blanket of flysch deposits. The latter represented the fill of the then forming Central Carpathian Paleogene Basin (Jacko \& Janoko 2000) in the northern part of the Tatricum realm.
The second stage of the deformation of the PKB was related to the Miocene orogenic processes in the Outer Carpathians (e.g. Oszczypko 2006 and references therein). Consequently, the original structure of the PKB was obliterated by local thrust- and strike-slip faulting, tectonic slicing and formation of out-of-sequence faults. The PKB became further fragmented into isolated klippen. In the opinion of Oszczypko \& Oszczypko-Clowes (2014), who documented an occurrence of Miocene sediments (Kremna Fm.) in the Magura Nappe and within the PKB, the nappes of the $\mathrm{PKB}$, together with the Grajcarek sheets, overode on a shallow dipping thrust the Miocene sediments of the Magura Nappe. In their conception, the PKB in the Małe Pieniny Mts. does not represent a sub-vertical and deep-rooted structure and it is only a zone of tectonic remnants floating on the rear rim of the Magura Nappe. The age of the folding and thrusting is ascribed by the latter authors to the Early Miocene, i.e. it must have occurred after the deposition of the Kremna Fm.

\section{INFLUENCE OF THE PLATFORM BASEMENT ON THE PKB STRUCTURE}

During the Miocene formation of the Outer Carpathians accretionary prism, the North-European platform was underthrust below the nascent orogen, undercutting and underplating the $\mathrm{PKB}$ and the Tatricum massifs located in the south. This underplated platform basement, with a number of deep fracture zones, must have influenced the overlying geological structure of the PKB. The fault pattern within the North-European Platform mostly dates back to the Variscan orogeny and earlier events. Important major faults are generally subparallel to the Teisseyre-Tornquist Zone (e.g. Pożaryski 1991, Guterch \& Grad 2006), that is they are oriented NNW-SSE. A regional-size major fault, of a deep fracture zone nature, is the Kraków-Myszków Fault Zone, defining a contact between the Małopolska and Upper Silesian blocks and representing a Paleozoic terrane boundary (Żaba 1996, Buła \& Żaba 2008). A southeastern extension of this fault is likely the Dunajec Fault, which (Figs. 2, 3), at its eastern side, offsets the PKB by $700 \mathrm{~m}$ to the south (Birkenmajer 1979). 


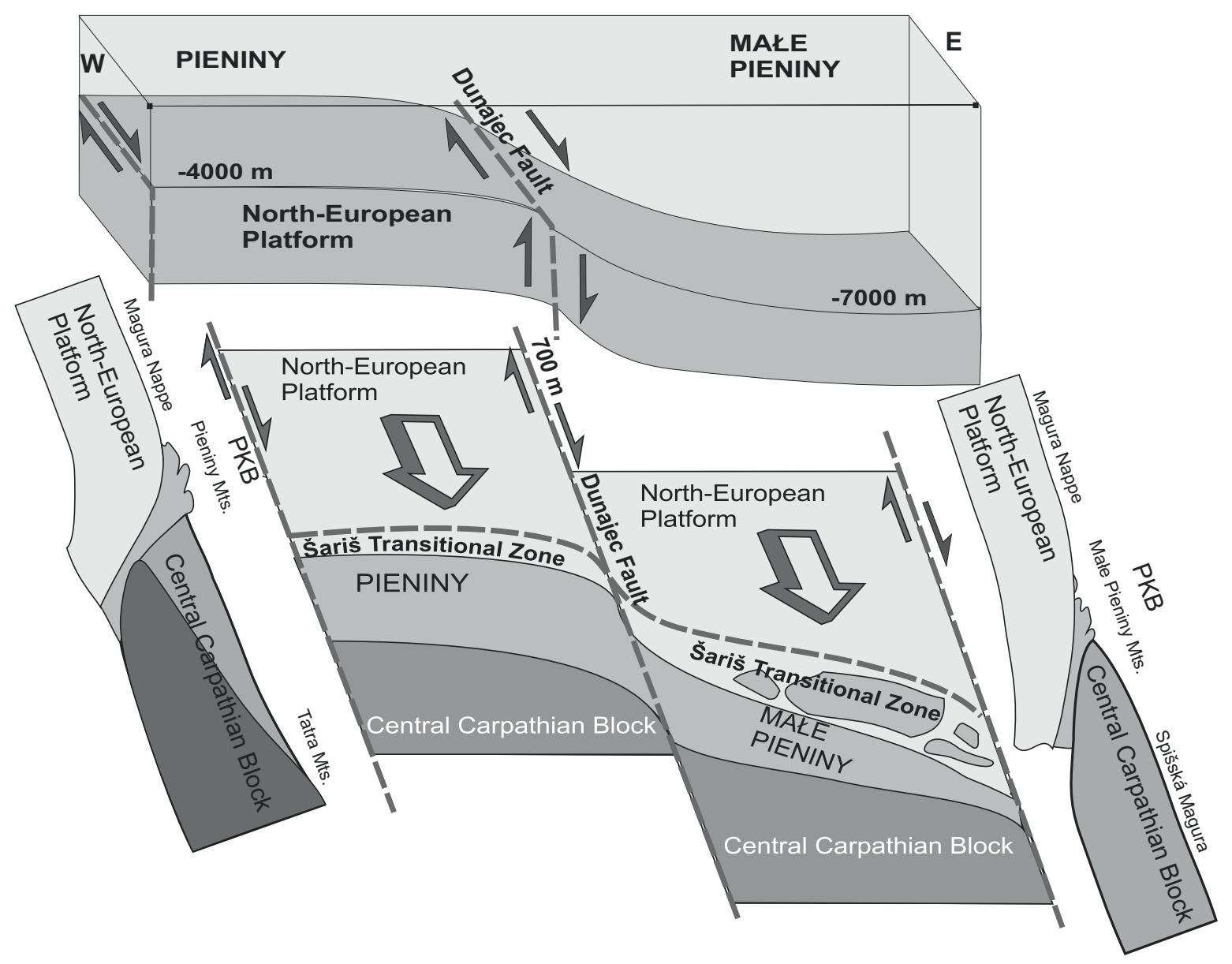

Fig. 3. Schematic diagram of the relationships between the North-European Platform, Central Carpathian Block and the PKB trapped between the two (not to scale). Note the differences between two segments of the PKB: the Pieniny and Mate Pieniny Mts.

The Dunajec fault thus seems to represent a mantle rooted fracture in the basement of the Outer Carpathians (Jurewicz 2005, Jurewicz et al. 2007, Nejbert et al. 2012). Along the course of this fault, the platform basement under the Outer Carpathians occurs $3000 \mathrm{~m}$ deeper on its eastern than on the western side (Zuchiewicz \& Oszczypko 2008). The Dunajec Fault has repeatedly been activated as a dextral strike-slip fault (see Buła \& Żaba 2008).

During one of its latest activation stages in the Miocene, andesitic rocks were emplaced along an "en échelon" system of second-order faults adjacent to the Dunajec Fault. The isotopic K-Ar dating of Birkenmajer \& Pécskay (1999) indicated two phases of volcanic activity there in the interval of 12.5-10.8 Ma (see Anczkiewicz \& Anczkiewicz 2016). A parental magmatic chamber of the andesites may have been located at a depth of ca 10-12 km. The chemical composition of the andesites from the area in question is not typical of andesites from subduction zones, and its formation may rather be linked with a deep fault zone (Pin et al. 2004, Jurewicz \& Nejbert 2005). In the vicinity of Szczawnica, Leśniak et al. (1997) documented a strong mantle helium signal related to andesites.

Pieniny andesites must have been generated in a metasomatised lithosphere of the European plate. Its partial melting may have been triggered by a local rise of asthenospheric material, related to reactivation of dextral motion on the Dunajec Fault. It might have also been connected with zones of adhesion originating as a result of fault-related shearing processes. The youngest stage of the Dunajec Fault activity is documented by extensional fractures in andesites, filled with flowstone-like calcite. The U-Th age of this calcite is $\sim 2.5-6.5$ ka (Jurewicz et al. 2007). Along the southern prolongation of the Dunajec Fault, near Ružbachy, travertine occurrences can be observed. 


\section{THE GRAJCAREK SUCCESSION AND SOME CONTROVERSIES CONCERNING ITS STRATIGRAPHY}

The Šariš Transitional Zone involves some Jurassic-Lower Cretaceous deposits of the Grajcarek Succession which are strongly folded due to two reasons: their frontal position during the late Cretaceous-Paleogene nappe-stacking and their mechanically weak dominant lithology. The Grajcarek Succession represents a facies-bathymetric zone of a basin installed to the north of the submarine Czorsztyn Swell (pre-Late Albian Magura Basin of Barski et al. 2012). Dark micaceous mudstones with sandy-crinoidal turbidite beds, ascribed to the Szlachtowa Fm. (Birkenmajer 1977), are typical of the lowermost part of the Grajcarek Succession. According to Birkenmajer (1977) and Birkenmajer \& Gedl (2017), deposition of the Szlachtowa Fm. also stretched over the Branisko Czertezik and Niedzica successions on the southern slope of the Czorsztyn Swell (ridge). However, the stratigraphic interval of the Szlachtowa Fm. is occupied by the Harcygrund and Podzamcze fms. or by a well-constrained sedimentary hiatus (Barski et al. 2012; see also Krobicki \& Wierzbowski 2004). Moreover, the key sections of the Szlachtowa Fm. at Czorsztyn-Podubocze, attributed earlier to the Branisko Succession (Birkenmajer 1963), were reinterpreted by Barski et al. (2012 - Fig. 2), following the view of Horwitz (1963), as the Grajcarek Succession.

The stratigraphic position of the Szlachtowa Fm. has been the focus of a long and bitter dispute (see Barski et al. 2012 and references therein). Two preclusive attributions, based on different microand macrofossil groups, include: Albian-Cenomanian (e.g. Sikora 1962, Oszczypko et al. 2004, Oszczypko et al. 2012) and Middle Jurassic (e.g. Andrusov 1929, Birkenmajer et al. 2008, Barski et al. 2012) (see Fig. 4) . The substantial disagreement over the Jurassic vs. Cretaceous age of the Szlachtowa Fm. was exemplified on geological maps of the Szczawnica-Jaworki area (see Golonka \& Rączkowski 1984, Oszczypko et al. 2012 Fig. 1B vs. Birkenmajer 1970, Książkiewicz 1972).

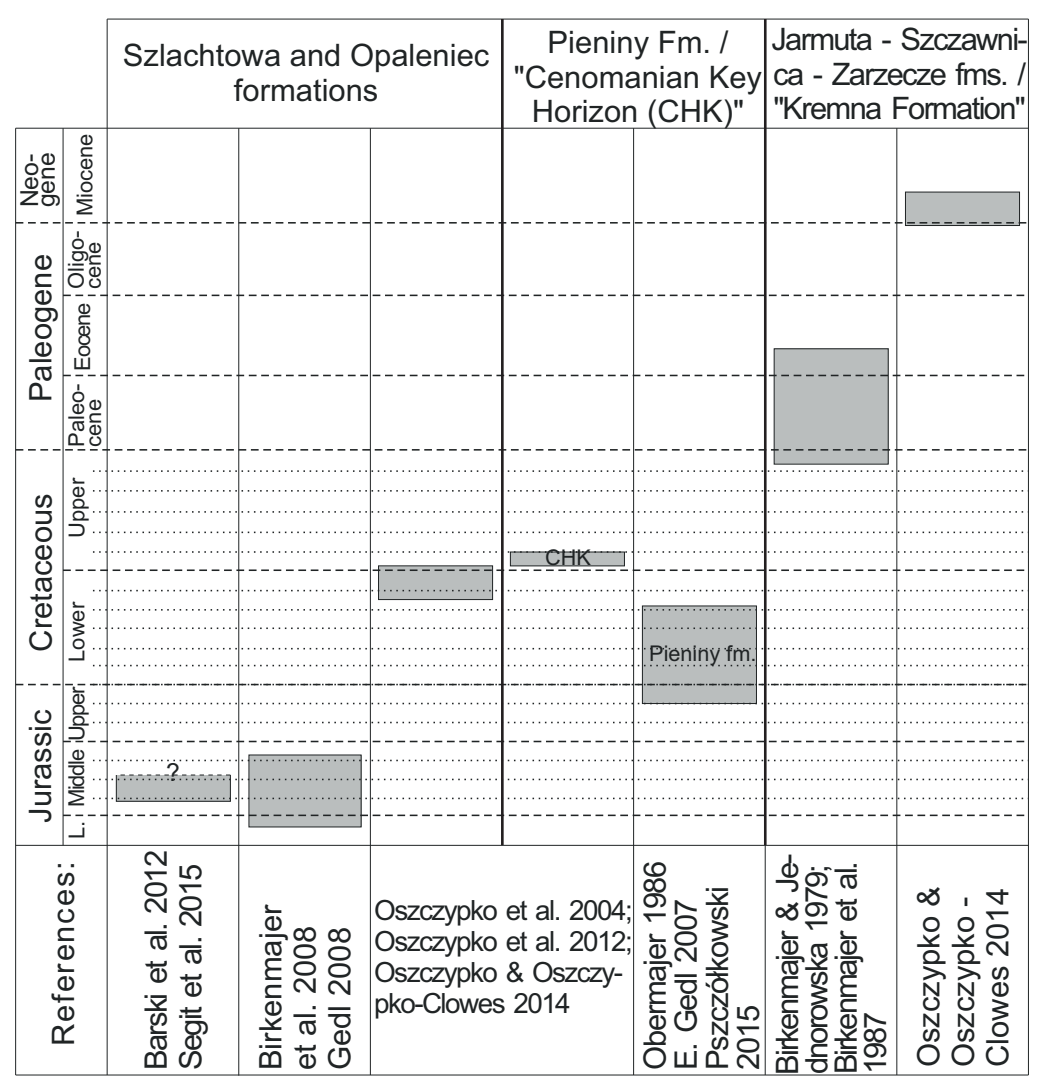

Fig. 4. Chrono- and lithostratigraphic assignments made for the same deposits of the Grajcarek or flysch Magura successions by different authors 
Disparate opinions in favour of the Jurassic age involve two overlapping stratigraphic ranges: upper Lower to lower Middle Jurassic, with some hiatuses (Gedl 2008) and exclusively lower Middle Jurassic (Barski et al. 2012, Segit et al. 2015).

Palynostratigraphic studies on the Szlachtowa Fm. carried out in the past decade, revealed well preserved dinoflagellate cysts indicating the uppermost Aalenian/lowermost Bajocian to lower Upper Bajocian interval (e.g. Barski et al. 2012, see also Gedl 2008, 2013). The stratigraphic order of dinoflagellate cyst assemblages (Segit et al. 2015) and the unique finding of Graphoceratidae ammonite (Gedl et al. 2012) testified to the in situ occurrence of Middle Jurassic palynomorphs and macrofossils in the Szlachtowa Fm. (i.e. not reworked into the Cretaceous). Upper Lower Jurassic Szlachtowa Fm., purportedly underlying the Krempachy Fm., was propounded by Birkenmajer (1977). Birkenmajer \& Gedl (2017) argued recently, that the Szlachtowa Fm. of the Branisko Succession at Podubocze Creek (from where Gedl (2008) and Barski et al. (2012) recovered Lower Bajocian palynomorphs) is directly overlain by the Krempachy Fm. The Krempachy Fm. in the section in question yielded abundant Lower Aalenian ammonites (Myczyński 1973, Birkenmajer 1977, Gedl 2008) which contradicts the suggested superposition.

Regarding the source of Cretaceous stratigraphic record ascribed to the Szlachtowa Fm., it may have come from: (1) tectonic slices of some Cretaceous strata mistaken for the Szlachtowa Fm., (2) uncertain lithostratigraphic attribution and misinterpreted location of archived samples (e.g. samples collected by E. Blaicher in the 1960-70s in Oszczypko et al. 2012), (3) incorrect taxonomic determination of foraminifera in typically impoverished, poorly preserved or consisting of not age-diagnostic species assemblages in the true Szlachtowa Fm. (see also Tyszka 1995, Gedl \& Jozsa 2015).

The Szlachtowa Fm. is overlain by the spotted-marly Opaleniec Fm., which yielded rich and well preserved palynomorph assemblages of the lowermost Upper Bajocian to Lower Bathonian (with no data on the uppermost part of the formation; Segit et al. 2015) or the uppermost Lower Bajocian to Callovian interval (Gedl 2008, 2013). Oszczypko et al. (2012) referred the Opaleniec
Fm. at Jaworki/Szlachtowa to the Sprzycne beds from the Spisz sector of the Pieniny Klippen Belt (Sikora 1962, 1971) of alleged Cenomanian age. The Sprzycne beds, however, proved to comprise tectonically amalgamated Jurassic and Cretaceous strata, erroneously attributed entirely to the Cretaceous by Sikora (1972) (Segit et al. 2015).

In contrast to the Szlachtowa and Opaleniec fms., the overlying sequence of radiolarites (Sokolica and Czajakowa fms.), red marly limestones (Pustelnia Marl Mb. of the Czorsztyn Fm.), Maiolica limestones (Pieniny Fm.) and spotted-marly limestones (Kapuśnica Fm.) have close facies and stratigraphic equivalents in the Pieniny Klippen Basin (see Birkenmajer 1977). These deposits cover the Bathonian/Callovian to Aptian combined interval (see Birkenmajer \& Gedl 2017). The thickness of the Maiolica limestones in the Grajcarek succession is considered significantly thinned in comparison to the Branisko-Pieniny Succession (2-6 m vs. 90-180 m, respectively; Birkenmajer \& Gedl 2017). Tectonic boundaries as well as the diverse stratigraphic position of individual sections (see Gedl 2007, Pszczółkowski 2015) suggest that the Klippen of the Pieniny Fm. in the Grajcarek Succession represent tectonically reduced blocks or olistoliths being parts of possibly quite a thick succession. The upper portion of the Pieniny Fm. is usually attributed to the upper Barremian or lower Aptian (Fig. 4) (see Gedl 2007, Pszczółkowski 2015 and citations therein). According to Oszczypko et al. (2012), it represents the Albian-Cenomanian. Pszczółkowski (2015) pointed out that the stratigraphic ranges of calcareous nannofossils diagnostic for the "Cenomanian Key Horizon" of Oszczypko et al. (2012) are actually Hoterivian-Cenomanian.

\section{NEOGENE KREMNA FORMATION VS. EARLY PALEOGENE JARMUTA- SZCZAWNICA-ZARZECZE FORMATIONS}

The synorogenic olistostrome (Jarmuta Fm.) passes to the north into sandstones alternating with mudstones and claystones (Szczawnica Fm). The flysch deposits of the Szczawnica Fm. represent part of the Magura Basin, distal with regard to the Laramian thrusting front (Jurewicz 1997). 
Calcareous nannoplankton recovered from the Jarmuta Fm. in Czarna Woda north of Jaworki, indicated Maastrichtian to Middle Paleocene interval (Birkenmajer et al. 1987), whereas the overlying Szczawnica Fm. yielded Middle Paleocene to possibly Early Eocene species (Birkenmajer \& Jednorowska 1979). Although the chronostratigraphy of the boundary of the Szczawnica and Zarzecze fms. is not well constrained (see Waśkowska \& Golonka 2016) it has been widely accepted that both units represent lower Paleogene.

A completely different interpretation of the stratigraphy and tectonics of the Szczawnica Jaworki area was given by Oszczypko \& Oszczypko-Clowes (2014). They attributed the whole flysch succession exposed between (and partially including) the Jarmuta Fm. in the south and the Magura Fm. in the north to the Kremna Fm. (Oszczypko et al. 2005) of supposedly latest Oligocene to Early Miocene age, as based on calcareous nannoplankton (zones NN1 and NN2) (Fig. 4).

The stratigraphic and taxonomic documentation of the Kremna Fm. at Jaworki in Oszczypko \& Oszczypko-Clowes (2014) suffer, however, from some imperfections. First, figures showing detail position of sampled beds in the sections studied are lacking; exemplary outcrops of typical lithofacies and small-scale cross sections were illustrated instead. The situation of the exotic pebbly mudstones of the Jarmuta Fm. in the middle course of the Czarna Woda Creek as proposed by Oszczypko \& Oszczypko-Clowes (2014) is confusing; the area and lithology described therein were attributed elsewhere in the same paper to the Kremna Fm.

It should be stressed that partial or total substitution of the Jarmuta, Szczawnica and/or Zarzecze fms. (see Birkenmajer \& Jednorowska 1979, Golonka \& Rączkowski 1984, Birkenmajer et al. 1987) for the Kremna Fm. (as in Oszczypko \& Oszczypko-Clowes 2014) in the area to the north of Szlachtowa and Jaworki was intrinsically illegitimate. This interpretation was invalidly founded upon the priority of chronostratigraphic equivalence over the lithologic/facies identity of lithostratigraphic units. On the premise that the considered deposits (i.e. Jarmuta, Szczawnica and Zarzecze fms.) were age-equivalent to the Kremna Fm., but had significantly different lithology, the individual lithostratigraphic assignments should have been retained. According to Oszczypko \& Oszczypko-Clowes (2014), the Kremna Fm. can be characterized by the presence of thin to medium-bedded carbonate flysch with intercalations of thick to very thick-bedded sandstones and conglomerates, as well as exotic paraconglomerates and thick marly beds and laminated sandy limestones and dark grey marl mudstones with Chondrites ichnofacies. Regarding the Jarmuta Fm., it is represented by thick-bedded turbidites, conglomerates and sandstones with subordinate intercalations of grey marly shale and locally contains debris flow paraconglomerates, whereas the Szczawnica and Zarzecze fms are composed of sandstone-dominated turbidites (see Oszczypko \& Oszczypko-Clowes 2014). These characteristics are not sufficient to unambiguously infer a lithological distinction or identity of the deposits in question with regard to the Kremna Fm. If, in terms of chronostratigraphic and lithologic/facies features, the Kremna Fm. were to be equivalent to the considered deposits, then the "Kremna Formation" would have been a junior synonym of the lithostratigraphic units representing these deposits and should have been discarded.

\section{SELECTED KEY PROBLEMS OF THE PKB GEOLOGY: THREE FIELD EXAMPLES}

The primary aim of presenting the three localities described below is to clarify the issue of the northern limit of the PKB, which, at the same time, also defines the boundary between the Outer and Central Carpathians (see Birkenmajer 1986, Jurewicz 2018 and references therein). The secondary aim is to highlight the currently underestimated impact of heterogeneity of the underplated North European platform on the tectonic evolution and present-day structure of the PKB. Yet another aim is to show the type area and exposures of the Grajcarek Succession and lowermost flysch Magura Succession which were involved to a large extent into the accretionary prism during the Late Cretaceous-Paleocene formation of the PKB. The context of major stratigraphic misconceptions related to these deposits are also to be presented and discussed in light of the newly acquired stratigraphic evidence. 


\section{STOP 7}

\section{Zawiasy}

$49^{\circ} 26^{\prime} 00^{\prime \prime} \mathrm{N} ; 20^{\circ} 26^{\prime} 18^{\prime \prime} \mathrm{E}$ (see Figs. 1,2 for location)

Role of the Dunajec Fault in the tectonic evolution of the $P K B$

Edyta Jurewicz

The Dunajec Valley is a good spot to highlight the impact of the heterogeneity of the underplated North European Platform on the tectonic evolution and present-day structure of the PKB. The
Dunajec Fault which can be correlated with the deep rooted Kraków-Myszków Fault Zone (Żaba 1996, Jurewicz 2005, Nejbert et al. 2012) has divided the PKB into two different segments: the Pieniny Mts. to the west and the Małe Pieniny Mts. to the east of it. Towards the east, the PKB becomes consecutively more fragmented into isolated klippen and its northern limit becomes progressively more difficult to delineate.

The main differences between both areas are presented in Table 1.

Table 1

The main geological differences between the Pieniny and Małe Pieniny Mts.

\begin{tabular}{|l|l|}
\hline \multicolumn{1}{|c|}{ Pieniny Mts. } & \multicolumn{1}{c|}{ Małe Pieniny Mts. } \\
\hline $\begin{array}{l}\text { Dominant units: Pieniny, Branisko } \\
\text { (in the south additionally Haligovce Unit) }\end{array}$ & $\begin{array}{l}\text { Dominant units: Czorsztyn, Niedzica, Branisko (lack of } \\
\text { Pieniny Unit) }\end{array}$ \\
\hline The structure is coherent & The structure is composed of isolated klippen \\
\hline Layers are mostly steeply dipping & Layers are shallowly dipping \\
\hline Platform basement is shallower $(-4000 \mathrm{~m})$ & Platform basement is deeper $(-7000 \mathrm{~m})$ \\
\hline There is rigid block of Tatra Mts. in the south & There is no rigid block in the south \\
\hline $\begin{array}{l}\text { Transitional zone along northern boundary of the PKB is } \\
\text { narrower }\end{array}$ & $\begin{array}{l}\text { Transitional zone along northern boundary of the PKB is } \\
\text { wider }\end{array}$ \\
\hline
\end{tabular}

The arguments in favor of the Dunajec Fault's (DF) connection with the Kraków-Myszków Fault Zone (KMFZ) are listed below:

- DF is one of the NNW-SSE fault zones sub-parallel to the TTZ;

- DF shows the same trend and it occurs at a direct continuation of the KMFZ;

- the same dextral strike slip movement is observed on DF at the PKB offset, connected with Miocene transpression (Birkenmajer 1977, 1986);

- the platform basement is in $3000 \mathrm{~m}$ deeper on the DF' s eastern side (Zuchiewicz \& Oszczypko 2008);

- andesite dykes are in "en echelon" position with respect to the DF (Jurewicz et al. 2007);

- chemical composition of andesites is typical of a deep fault zone associated by adiabatic decompression of upper mantle, related to shearing processes and a pull-apart displacement (Pin et al. 2004, Nejbert et al. 2012);

- magmatic chamber of andesites could have been located at a depth of 10-12 km (Nejbert et al. 2012);
- there is a strong mantle helium signal connected with andesites (Leśniak et al. 1997);

- there is neotectonic activity (6000 k) along DF indicating the same dextral shearing as that on KMFZ (Jurewicz et al. 2007);

- there is a travertine occurrence along the DF near Ružbachy.

\section{STOP 8}

Krupianka Creek and Baba Rock

$49^{\circ} 24^{\prime} 15^{\prime \prime} \mathrm{N} ; 20^{\circ} 32^{\prime} 25^{\prime \prime} \mathrm{E}$

(see Figs. 1, 2 for location)

The Šariš Transitional Zone

Edyta Jurewicz

At the base of the Baba Rock one can ask: Where are we? In the PKB or in the Outer Carpathians?

The answer is not easy because of displacements and other interactions between the PKB and Outer Carpathians during the sedimentation and deformation stages of their development which have resulted in a difficult-to-delimit, transitional zone. Until now, in the structural sense, this zone had 
the rank of a tectonic unit. It was termed the Grajcarek (in Poland) or Šariš Unit (in Slovakia) but the northern boundary of this "unit" was difficult to recognize in the field. The tectonic deformations in this area gradually vanish towards the north, and therefore one could not know if the boundary should be put along the "last thrust-fault" or on the "last olistolith" (?). In the opinion of this author, the sediments in the Krupianka Creek near the Baba Rock (Fig. 5) should not be ascribed to a separate tectonic unit, but considered only as occurring in a distinct zone of deformation (Jurewicz 1994, 1997). This zone, transitional in its nature, consists of strongly deformed slices composed of Jurassic-Cretaceous sediments originated in the peri-klippen Grajcarek (pre-Albian Magura) Basin and synorogenic wild-flysch rocks, breccia type sediments and numerous olistoliths composed of klippen units. This zone can therefore be defined as a peri-klippen part of the Magura Nappe which lacks a distinct northern tectonic limit. To discriminate it with the Grajcarek Basin, it is named the Šariš Transitional Zone (because it is not only the sediments from the Grajcarek Basin that are included to this zone). The name "Grajcarek" will be reserved to the lithostratigraphic succesion of the Grajcarek Basin (Birkenmajer \& Gedl 2017), which existed during Jurassic to Early Cretaceous times in the southernmost (peri-klippen) part of the Magura (pre-Albian Magura) Basin.

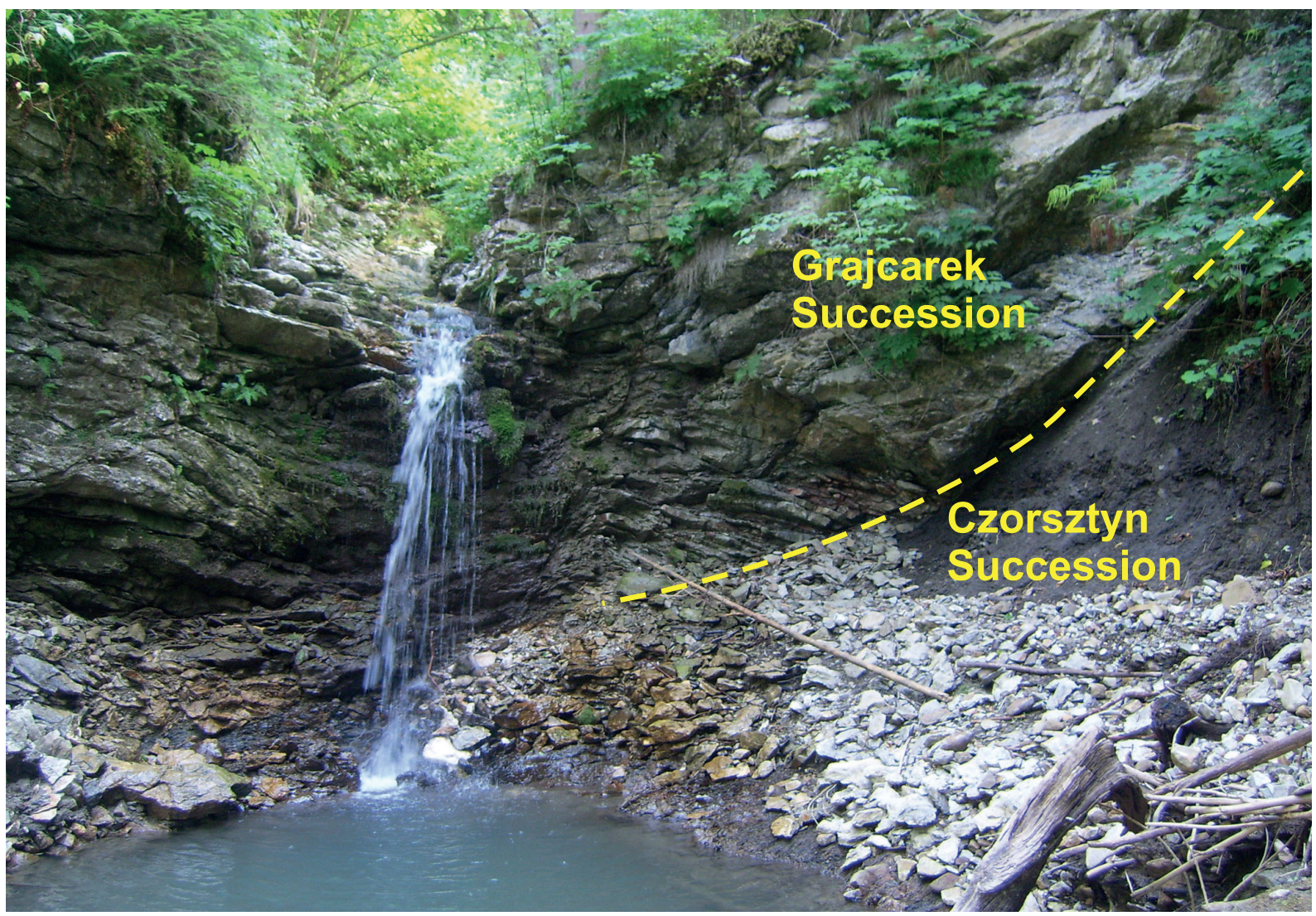

Fig. 5. Šariš Transitional Zone: outcrop of the Jurassic-Lower Cretaceous sediments of the Grajcarek Succession, resting at the base of the Baba Rock

\section{The Czorsztyn Succession in Krupianka Creek Tomasz Segit}

The Krupianka Creek, as well as the adjacent Homole Gorge, are unique along the Pieniny Klip- pen Belt in that they show the fairly complete mid-Jurassic-Cretaceous strata of the Czorsztyn Succession lying almost flat. The lowermost beds in the sequence are grey and black shales of the Skrzypny Fm. (Fig. 6A). These deposits differ from 
the Szlachtowa Fm. in their lack of turbidites, paucity of mica flakes, more clayey composition and common presence of siderite nodules. Unlike the Krempachy Marl Fm., which underlies the Skrzypny Fm. elsewhere, the dark shales of the latter formation are not distinctively bioturbated (spotted) and therefore should not be associated with the Fleckenkalk/Fleckenmergel facies (cf. Krobicki \& Golonka 2008). Exposures of the Skrzypny Fm. in the Krupianka Creek yielded rich ammonite fauna (mainly Brasilia spp.) indicative of the Bradfordensis zone (Middle Aalenian) (see Myczyński 2004). Gedl (2008), on the basis of the impoverished dinoflagellate cyst assemblages, argued for a Lower and Middle Aalenian position of the same strata. The extensive ammonite collection from the Skrzypny Fm. (Myczyński 2004) clearly indicates that the basal part of this unit represents the Middle Aalenian (Murchisonae Zone). The sequence of the Skrzypny Fm. currently exposed in Krupianka Creek is probably not complete (partly covered) and lacks the Upper Aalenian component.

The Pieniny Klippen Basin witnessed a major facies changeover in the Early Bajocian (see Krobicki \& Wierzbowski 2004). The rising of the Czorsztyn Ridge led to the formation of individualized bathymetric zones - the successions. The position of the Czorsztyn Succession was the shallowest and thus prone to emersion, winnowing and condensation. The Lower Bajocian hiatus, which involved some shallow parts of the basin, is recorded in the lowermost part of the massive crinoidal limestones (Smolegowa Fm.), directly above the Aalenian shales. These beds yielded phosphatic nodules, lithoclasts of green micritic limestones and ammonites diagnostic of the uppermost Lower Bajocian (see Krobicki \& Wierzbowski 2004, Wierzbowski et al. 2004).

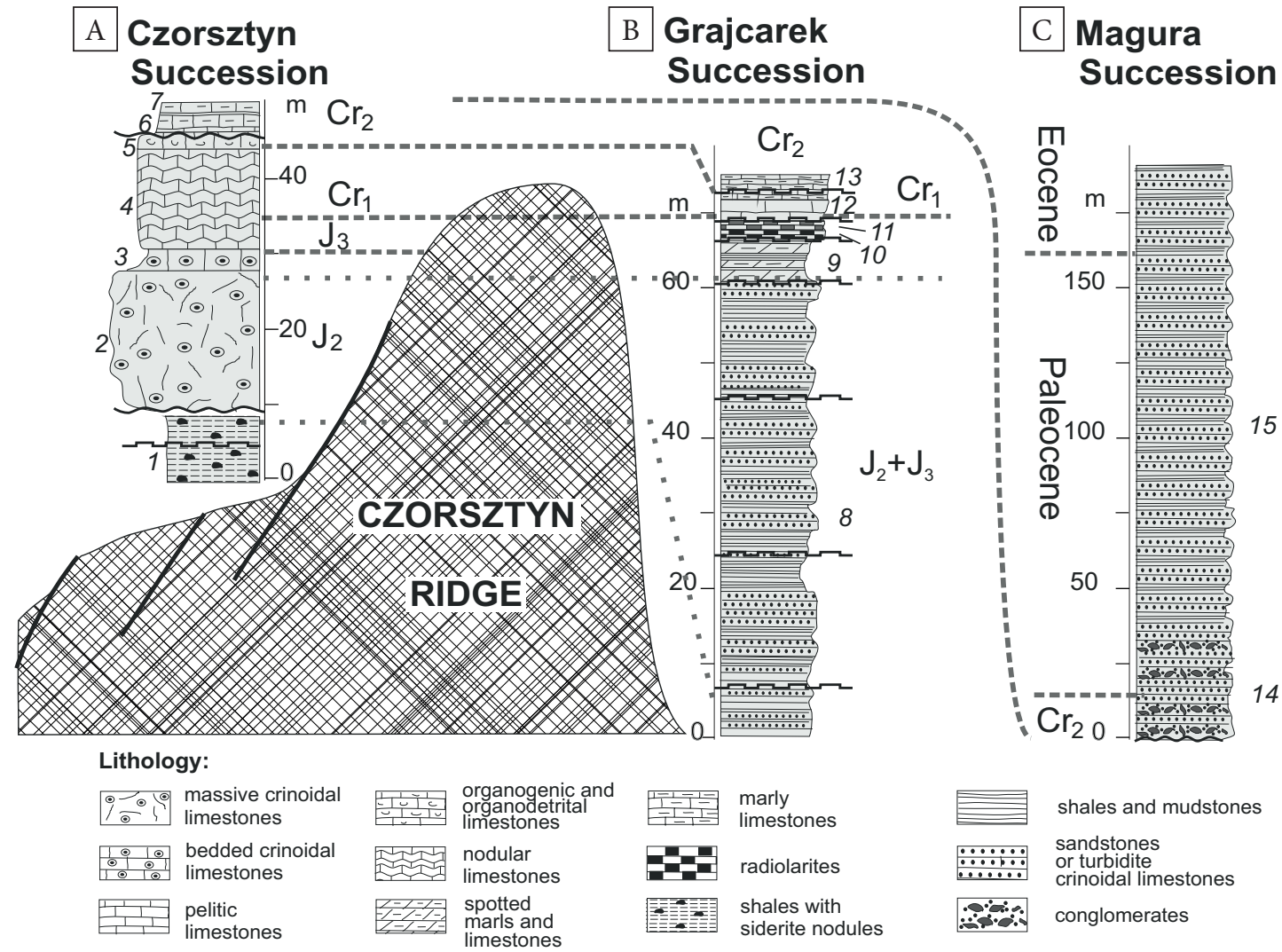

Fig. 6. Lithostratigraphic columns of the Czorsztyn and Grajcarek successions in Krupianka Creek (A, B) and flysch Magura Succession of the peri-klippen zone (C) (stratigraphy after: Birkenmajer 1970, 1977, Wierzbowski 1994, Wierzbowski et al. 1999, Krobicki \& Wierzbowski 2004, Barski et al. 2012, Plašienka et al. 2012, Segit et al. 2015, modified). A) Czorsztyn Succession (Pieniny Klippen Basin), formations: 1 - Skrzypny Shale; 2 - Smolegowa Limestone; 3 - Krupianka Limestone; 4 - Czorsztyn Limestone; 5 - Dursztyn Limestone, 6 - Chmielowa; 7 - Pomiedznik. B) Grajcarek Succession (of the pre-Late Albian Magura Basin), formations: 8 - Szlachtowa; 9 - Opaleniec; 10 - Sokolica Radiolarite; 11 - Czajakowa Radiolarite; 12 - Pieniny Limestone; 13 - Kapuśnica. C) Flysch Magura Succession s.s., formations: 14 - Jarmuta; 15 - Szczawnica and Zarzecze 
The contact of the Skrzypny and Smolegowa fms. is not exposed, except for the base of the limestone blocks that slid down the slope of the ravine (see Krobicki \& Wierzbowski 2004). Abundant lithoclasts and concretions probably constitute the residue of green phosphatic shales, analogous to these recognized at base of the Smolegowa Fm. in Slovakia (Segit 2010). The thickness of the crinoidal limestone in Krupianka Creek, reportedly amounting to ca. ?20 m (see Birkenmajer 1979) (the bottom not exposed), contrasts with $100 \mathrm{~m}$ in neighboring Homole Gorge and $150 \mathrm{~m}$ in Biała Woda Creek (Smolegowa Klippe), indicating intensive synsedimentary faulting (see Krobicki \& Wierzbowski 2004). White crinoidal limestones pass upward (following an omission surface) into the $1 \mathrm{~m}$ thick, thin bedded, fine-grained, reddish crinoidal limestones of the Krupianka Fm., attributed to the middle Upper Bajocian (Wierzbowski et al. 1999). Higher up in the sequence, above another hiatal interval, there occur red to violet- brown Amonitico Rosso limestones (Czorsztyn Fm.) with horizons of ferro-manganese nodules and encrustations (see Wierzbowski et al. 1999) of a total thickness ca. $15 \mathrm{~m}$. These nodular limestones embrace a wide stratigraphic range up to the Tithonian (see Wierzbowski 1994, Hudson et al. 2005). They are overlain by massive, pinkish and white Calpionella-bearing limestones (Dursztyn Fm.) representing the Berriasian. The Łysa and Spisz fms. (Berriasian to Valanginian, see Wierzbowski 1994), typically overlying the Dursztyn Fm. in the Czorsztyn Succession, are missing, probably due to pre-Albian erosion. The uppermost part of the sequence constitutes the red, very thin and discontinuous, post-emersion Chmielowa Fm. of the Albian age (Aubrecht et al. 2006), and poorly exposed, marly limestones and marls of the Pomiedznik Fm. (Birkenmajer 1979).

\section{The Grajcarek Succession in Krupianka Creek Tomasz Segit}

The incised ravine of the Krupianka Creek cuts off the western margin of the Homole-Biała Woda Block (Czorsztyn Succession). The creek bed erosion reached the base of the block and exposed deposits of the Grajcarek Succession, represented predominantly by the Szlachtowa Fm. ("black flysch") (Fig. 6B). The Opaleniec Fm. is just a few meters thick. The overlying, tectonically reduced sequence of the Sokolica, Czajakowa and Pieniny fms. (Birkenmajer 1979, Gedl 2008) was erroneously attributed by Oszczypko et al. (2012) to the Hulina Fm. and their "Cenomanian Key Horizon" (see the discussion in Birkenmajer \& Gedl 2017). The absence of the Palenica Mb. (Czorsztyn Fm.), a unit typical of the Grajcarek Succession (Birkenmajer 1977), is probably a tectonic perturbation. The Pieniny Fm. is capped by marlstones of the Kapuśnica Fm., best exposed in a section of a large waterfall in the upper part of the ravine (Fig. 5). Dinoflagellate cyst-based stratigraphic data of Gedl (2007) indicated Lower Aptian in the Kapuśnica Fm. at Szczawnica; Upper Aptian is favoured by Birkenmajer \& Gedl (2017). The Malinowa and Jarmuta fms. (see Birkenmajer 1979) delineate the boundary between the Grajcarek and Czorsztyn successions (Fig. 6C).

\section{STOP 9}

\section{Czarna Woda Creek}

$49^{\circ} 24^{\prime} 43^{\prime \prime} \mathrm{N} ; 20^{\circ} 33^{\prime} 37^{\prime \prime} \mathrm{E}$ (see Figs. 1, 2 for location) Tectonic position of synorogenic sediments of the Jarmuta-Proč Fm.

\section{Edyta Jurewicz}

In the Czarna Woda Stream, located less than $2 \mathrm{~km}$ to the north-east of the earlier stop, we are a little further from the PKB units. In this locality one can observe synorogenic sediments of the Jarmuta Fm. (Maastricht-Paleocene), chaotic in nature, originating from gravitational slumping and mass movement. We can find material coming from the folded klippen units as well as exotic fragments of crystalline rocks, e.g. basalts or gneisses. In one place we can see a convolute fold apparently developed in an uconsolidated layer of sandstone, in a gravity-driven debris flow (Fig. 7). It consists mainly of mudstone with numerous rounded pebbles. Middle Paleocene foraminifera and coccoliths (NP 5 zone) have been found by Birkenmajer \& Dudziak (1991) near this place, while Oszczypko \& Oszczypko-Clowes (2014) included these sediments into the Kremna Fm., Miocene in age. 


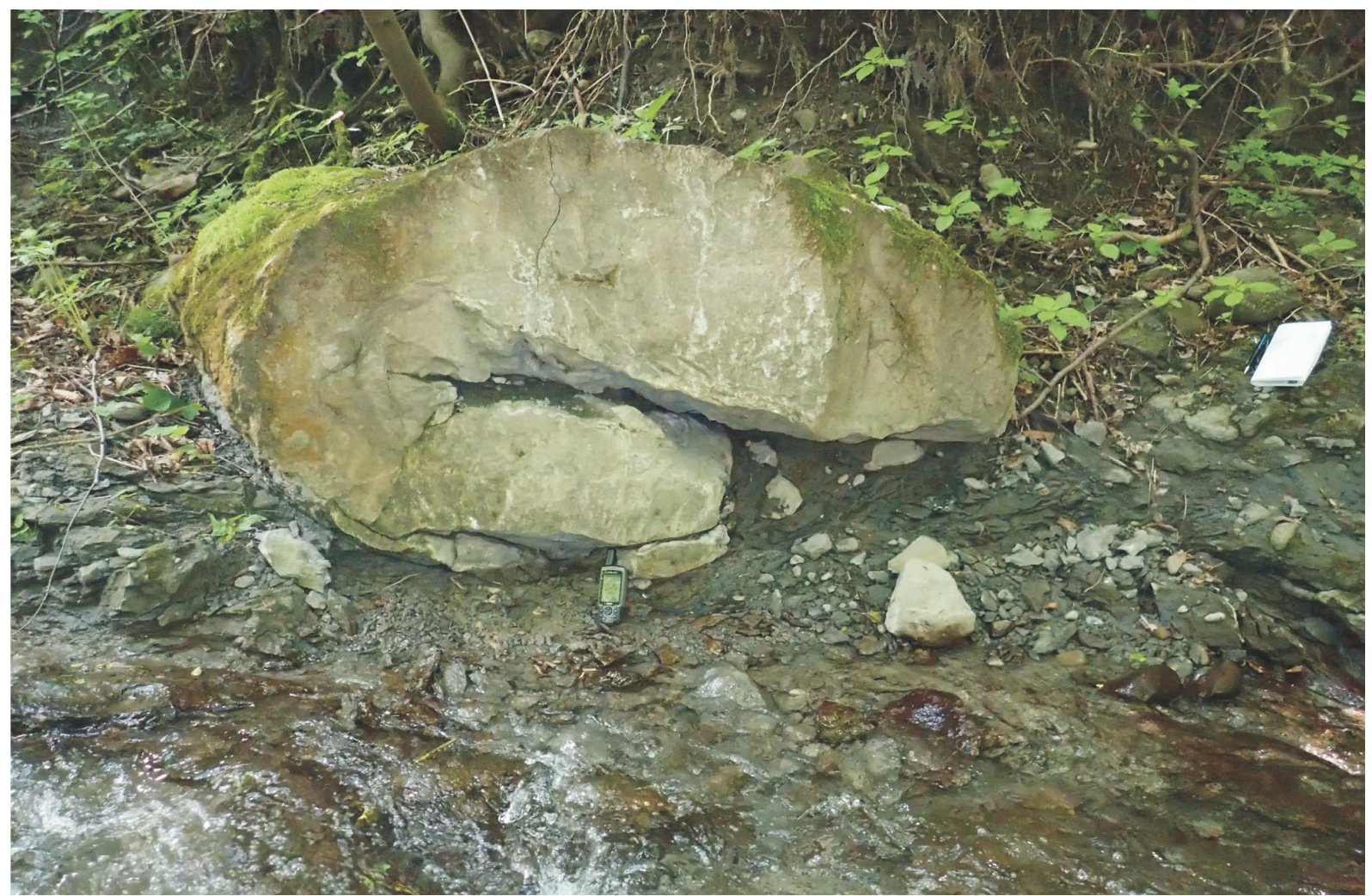

Fig. 7. Šariš Transitional zone: convolute fold formed by a gravity-driven slump incorporated into mudstone with numerous rounded pebbles of different lithologies and size

\section{Indigenous lower Paleogene dinoflagellate cysts in the "Kremna Formation" in the Czarna Woda Creek \\ Tomasz Segit}

Biostratigraphic studies on the Jarmuta Fm. in the Czarna Woda Creek to the north of Jaworki, carried out by Birkenmajer et al. (1987) provided nanoplankton evidence of the base Maastrichtian-Middle Paleocene interval. According to Birkenmajer \& Jednorowska (1979), the foraminifera assemblage recovered from the overlying Szczawnica Formation was indicative of the Paleocene. Oszczypko-Clowes \& Oszczypko (2014, see Fig. 2 therein) reattributed deposits that had earlier been treated as Jarmuta, Szczawnica or Zarzecze fms. (Birkenmajer \& Jednorowska 1979, Golonka \& Rączkowski 1984) to the Kremna Fm. and examined two samples of the latter unit from Czarna Woda Creek: WP381 and WP385. The sample WP381 proved barren, whereas the sample WP385 yielded the following nanoplankton species: Chiasmolithus gigas (Eocene), Coccolithus pelagicus (Paleocene-rec.), Discoaster barbadiensis (Eocene), Discoaster multiradiatus (Paleocene-Eocene), Helicosphaera compacta (Eocene-Lower Miocene), Pontosphaera plana (Paleocene-Oligocene), Sphenolithus conicus (Oligocene-Miocene), Sphenolithus moriformis (Paleocene-Quaternary), Toweius sp. (Paleocene-Eocene), Transversopontis pulcher (Paleocene-Eocene), Umbilicosphaera rotula (Miocene-Quaternary), Zygrhablithus bijugatus (Paleocene-earliest Miocene) (stratigraphic ranges after Young et al. - Nannotax3, on-line). The age of the sample was referred to the Early Miocene Discoaster druggii Zone (NN2). Neither the data on sample abundance, preservation, species frequencies nor illustrations of the species were given. Oszczypko-Clowes (2012), studying the section at Kremna and some other flysch deposits, found that redeposited nanoplankton species are often abundant or even dominant and better preserved than in situ species. According to Oszczypko-Clowes (2012), the redeposition had led to earlier stratigraphic misinterpretations of Miocene strata as Paleogene. This implied, however, that all 
the earlier works had provided deficient (incom- Neogene forms had been overlooked in the analplete) data on microfossil assemblages and that yses.

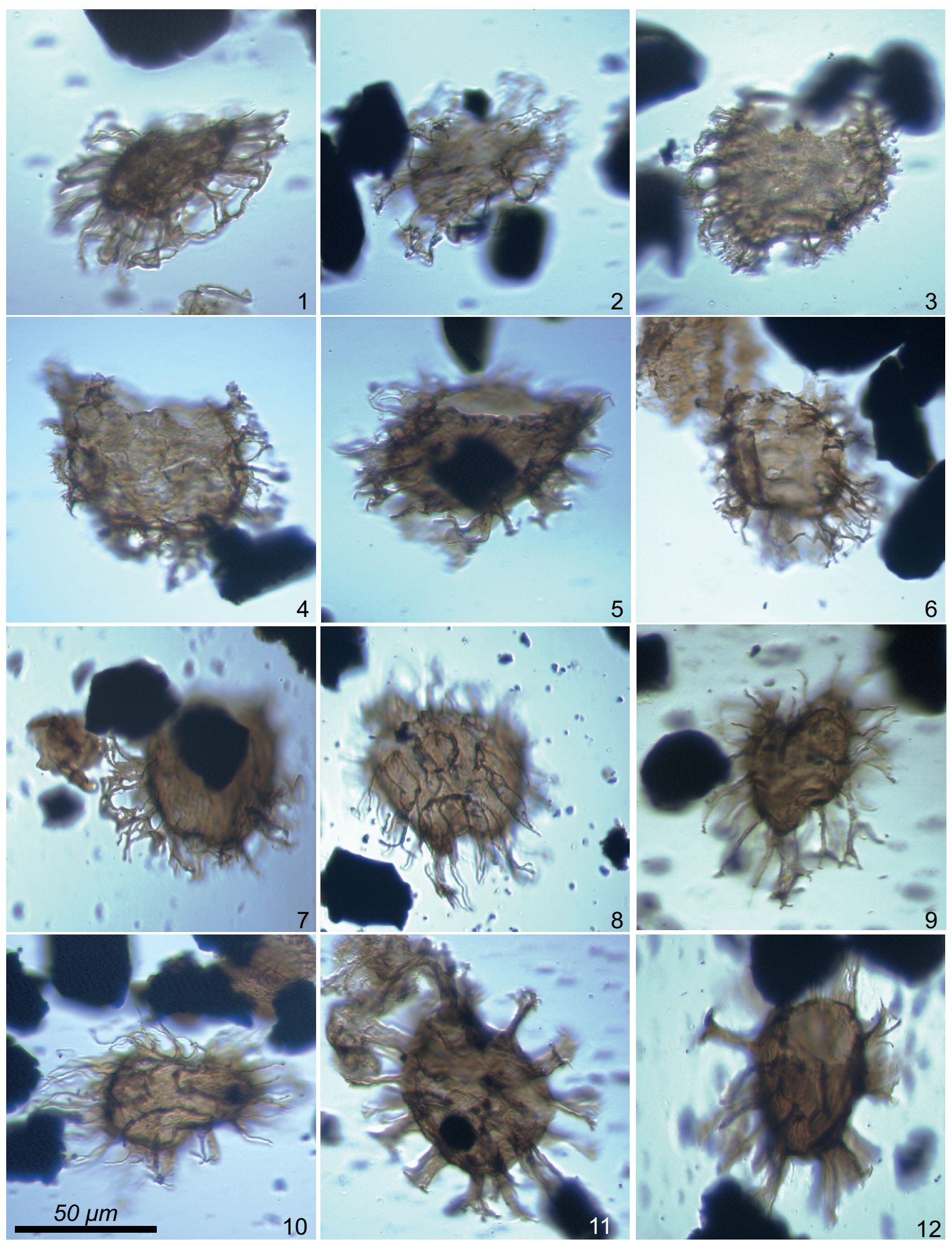

Fig. 8. The Paleogene dinoflagellate cysts characteristic of the sample CZW-1 from the Szczawnica Formation ("Kremna Fm."): 1 - Adnatosphaeridium robustum; 2 - Adnatosphaeridium cf. vittatum; 3, 5 - Glaphyrocysta divaricata; 4 - Glaphyrocysta cf. ordinata; 5, 6 - Areoligera senonensis group; 8, 9, 10 - Cleistosphaeridium diversispinosum; 11, 12 - Cordosphaeridium sp. Scale bar applies to all photographs 

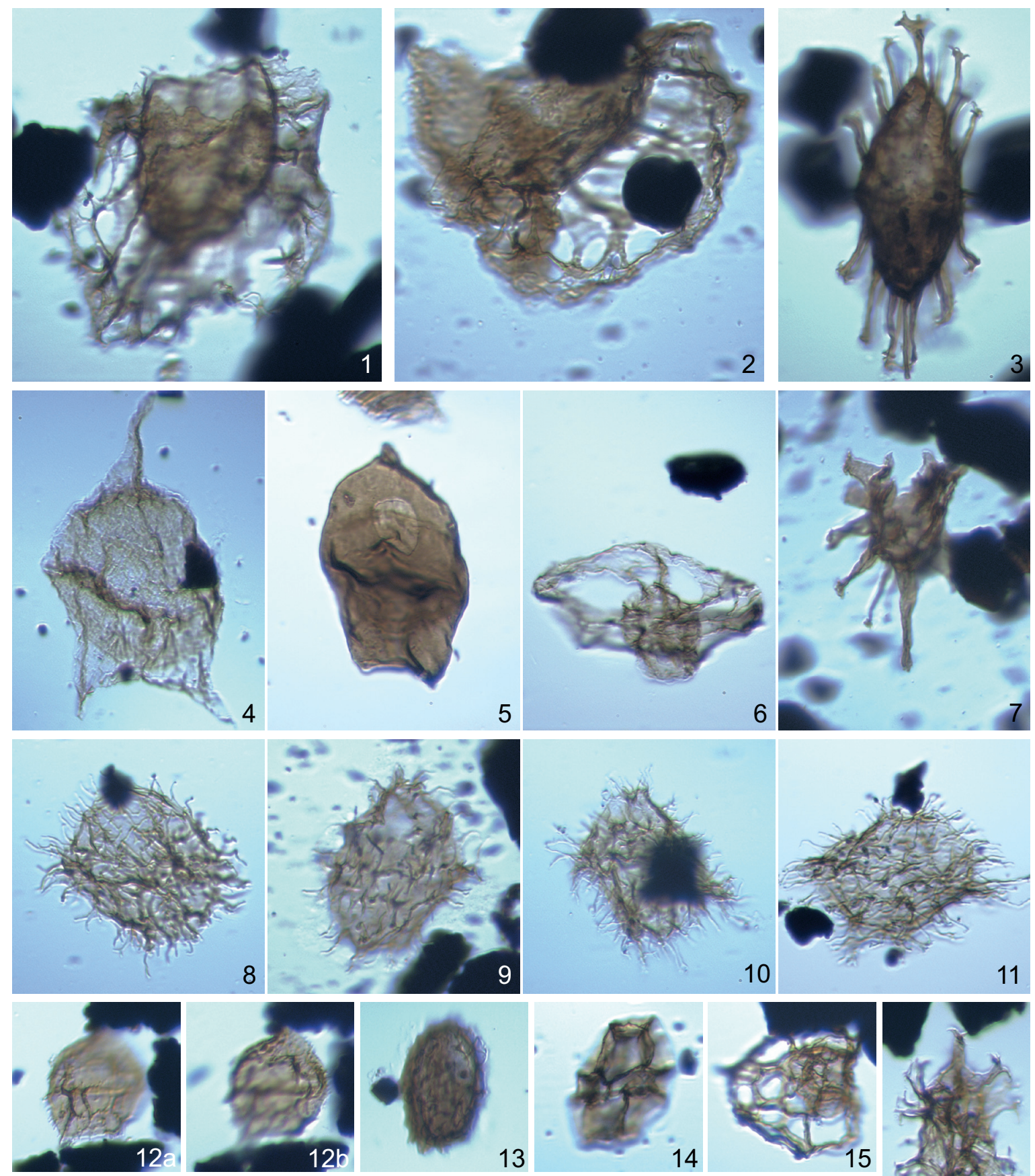

$50 \mu m$

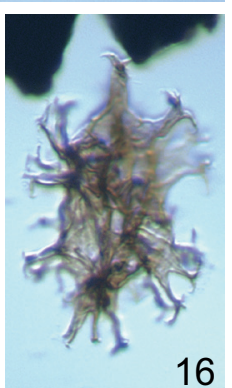

Fig. 9. The Paleogene and redeposited Cretaceous dinoflagellate cysts characteristic of the sample CZW-1 from the Szczawnica Formation ("Kremna Fm."): 1, 2 - Glaphyrocysta semitecta; 3 - Fibrocysta radiata/vectensis; 4 - Cerodinium speciosum; 5 - Isabelidinium cooksoniae (redeposited); 6 - Thalassiphora delicata; 7 - Hystrichokolpoma sp.; 8, 9, 10 - Apectodinium homomorphum; 11 - Apectodinium quinquelatum; 12a, b-Phthanoperidinium cf. regale (various focii); 13 - Cerebrocysta cf. bartonensis; 14 - Impagidinium sp.; 15 - Hapsocysta sp. (?redeposited); 16 - Spiniferites sp. Scale bar applies to all photographs

Because of the ensuing discrepancy in calcareous nano-/microfossils stratigraphy of the Jarmuta/ Szczawnica/"Kremna" formations, dinoflagellate cysts have been employed to provide independent stratigraphic data. A pilot sample of grey marls intercalating with sandstones was picked in the 
middle course of the Czarna Woda Creek (CZW-1, GPS position: N 49²4'45.9"; E 20³3'51.54"). These deposits were assigned to the Kremna Formation by Oszczypko \& Oszczypko-Clowes (2014). The recovered dinoflagellate cysts assemblage is moderately diverse and moderately well preserved (see Figs. 8, 9). The most stratigraphically significant taxa are suggestive of the ?uppermost Paleocene-lower Eocene: Apectodinium homomorphum, A. quinquelatum (uppermost Paleocene-lower Eocene), Cerodinium speciosum (Maastrichtian-lower Eocene), Areoligera senonensis (Cretaceous-Eocene), Fibrocysta radiata/vectensis (Paleocene-Eocene), Glaphyrocysta divaricata (upper Paleocene-Eocene), Cleistosphaeridium diversispinosum (lower Eocene-Miocene) and Thalassiphora delicata (Paleocene-lower Eocene) followed by less age-diagnostic or determined in question, yet common in upper Paleocene and/or Early Eocene: Glaphyrocysta semitecta, G. ordinata, Cerebrocysta cf. bartonensis, Operculodinium cf. nanaconulum, Phthanoperidinium cf. regale, Adnatosphaeridium robustum (stratigraphic ranges compiled from: Brown \& Downie 1984, Brinkhuis \& Leereveld 1988, Head \& Norris 1989, Bujak \& Mudge 1994, Powel et al. 1996, Iakovleva et al. 2001, Slimani et al. 2012, Soliman 2012, Mohamed et al. 2012, 2013, Mohamed \& Wagreich 2013, Țabără et al. 2017). Representatives of the genera Glaphyrocysta and Areoligera as well as A. homomorphum, and C. diversispinosum are common. Also present are several long-ranging taxa, e.g.: Spiniferites ramosus s.l., Homotryblium sp., Achomosphaera sp., Impagidinium sp. Oligosphaeridium sp., Cordosphaeridium sp. and Lingulodinium sp. The sample yielded some redeposited Cretaceous taxa: Isabelidinium cooksoniae, Litosphaeridium cf. siphoniphorum and Hapsocysta sp. Inasmuch as no marker species of the Oligocene or Miocene were found, the evidence is lacking to support the recycling of palynomorphs. Thus the inferred stratigraphic position of the sample studied is the lower Paleogene, most probably the lower Eocene.

The authors would like to express their gratitude to Prof. Pawet Aleksandrowski for critical reading of the manuscript and for fruitful discussion.

\section{REFERENCES}

Anczkiewicz A.A. \& Anczkiewicz R., 2016. U-Pb zircon geochronology and anomalous $\mathrm{Sr}-\mathrm{Nd}-\mathrm{Hf}$ isotope systematics of late orogenic andesites: Pieniny Klippen Belt, Western Carpathians, South Poland, Chemical Geology, 427, 1-16. DOI: 10.1016/j.chemgeo.2016.02.004.

Andrusov D., 1938. Étude géologique de la zone des Klippes internes des Carpathes Occidentales, $3 e$ partie: Tectonique. State Geological Survey, Prague.

Barski M., Matyja B.A., Segit T. \& Wierzbowski A., 2012. Early to Late Bajocian age of the so called "black flysch" (Szlachtowa Formation) depos its: implications for the history and geological structure of the Pieniny Klippen Belt, Carpathians. Geological Quarterly, 56, 391-410.

Birkenmajer K., 1959. Diapiric tectonics in the Pieniny Klippen Belt (Carpathians). Bulletin de l'Académie polonaise des sciences. Série des sciences chimiques, 7, 123-128.

Birkenmajer K., 1963. Stratygrafia i paleogeografia serii czorsztyńskiej pienińskiego pasa skałkowego Polski [Stratigraphy and palaeogeography of the Czorsztyn series, Pieniny Klippen Belt, Carpathians, Poland]. Studia Geologica Polonica, 9, 1-380.

Birkenmajer K. 1970. Przedeoceńskie struktury fałdowe w pienińskim pasie skałkowym Polski [Pre-Eocene fold structure fold structures in the Pieniny Klippen Belt (Carpathians) of Poland]. Studia Geologica Polonica, 31, 1-77.

Birkenmajer K., 1977. Jurassic and Cretaceous lithostratigraphic units of the Pieniny Klippen Belt, Carpathians, Poland. Studia Geologica Polonica, 45, 1-158.

Birkenmajer K., 1979. Przewodnik geologiczny po pienińskim pasie skałkowym. Wydawnictwa Geologiczne, Warszawa.

Birkenmajer K. \& Dudziak J., 1991. Middle to Late Palaeocene Nannoplankton Zones in the Jarmuta Formation, Pieniny Klippen Belt. Bulletin of the Polish Academy of Sciences, Earth Sciences, 39, 47-52.

Birkenmajer K. \& Gedl P., 2017. The Grajcarek Succession (Lower Jurassic-mid Paleocene) in the Pieniny Klippen Belt, West Carpathians: a stratigraphic synthesis. Annales Societatis Geologorum Poloniae, 87, 55-88.

Birkenmajer K. \& Jednorowska A., 1979. Paleoceńska mikrofauna $\mathrm{z}$ fliszu magurskiego na kontakcie $\mathrm{z}$ pienińskim pasem skałkowym [Paleocene foraminiferal assemblage from the Magura flysch at the contact with the Pieniny Klippen Belt at Jaworki, Carpathians, Poland]. Rocznik Polskiego Towarzystwa Geologicznego [Annales de la Société Géologique de Pologne], 49, 3-4, 287-292.

Birkenmajer K. \& Pécskay Z., 1999. K-Ar dating of the Miocene andesite intrusions, Pieniny Mts, West Carpathians. Bulletin of the Polish Academy of Sciences, Earth Sciences, 47, 155-169.

Birkenmajer K., Dudziak J., Jednorowska A. \& Kutyba J., 1987. Foraminiferal-nannoplankton evidence for Maastrichtian and Palaeocene ages of the Jarmuta Formation: its bearing on dating Laramian orogeny in Pieniny Klippen Belt, Carpathians, Poland). Bulletin of the Polish Academy of Sciences, Earth Sciences, 35, 287-298.

Birkenmajer K., Gedl P., Myczyński R. \& Tyszka J., 2008. "Cretaceous black flysch" in the Pieniny Klippen Belt, West Carpathians: a case of geological misinterpretation. Cretaceous Research, 29, 535-549. 
Brown S. \& Downie C., 1984. Dinoflagellate cyst biostratigraphy of Late Paleocene and Early Eocene sediments from Holes 552, 553A, and 555, Leg 81, Deep Sea Drilling Project (Rockall Plateau). [in:] Roberts D.G., Schnitker D. et al., Initial Reports of the Deep Sea Drilling Project, 81, U.S. Government Printing Office, Washington D.C., 565-579.

Brinkhuis H. \& Leereveld H., 1988. Dinoflagellate cysts from the Cretaceous/Tertiary boundary sequence of El Kef, northwest Tunisia. Review of Palaeobotany and Palynology, 56, 5-19.

Bujak J.P. \& Mudge D.C., 1994, A high resolution North Sea Eocene dinocyst zonation. Journal of the Geological Society London, 151, 449-462.

Buła Z. \& Żaba J., 2008. Struktura prekambryjskiego podłoża wschodniej części bloku górnośląskiego (Brunovistulicum) [Structure of the Precambrian basement of the eastern part of the Upper Silesian block (Brunovistulicum)]. Przeglad Geologiczny, 56, 473-480.

Froitzheim N., Plašienka D. \& Schuster R., 2008. Alpine tectonics of the Alps and Western Carpathians. [in:] McCann T. (ed.), The Geology of Central Europe. Volume 2: Mesozoic and Cenozoic, Geological Society, London, 1141-1232.

Gedl E., 2007. Lower Cretaceous dinocyst stratigraphy and palynofacies of the Grajcarek Unit, Pieniny Klippen Belt, West Carpathians, Poland. Studia Geologica Polonica, 127, 71-100.

Gedl P., 2008. Organic-walled dinoflagellate cyst stratigraphy of dark Middle Jurassic marine deposits of the Pieniny Klippen Belt, West Carpathians. Studia Geologica Polonica, 131, 7-227.

Gedl P., 2013. Dinoflagellate cysts from the Szlachtowa Formation (Jurassic) and adjacent deposits (Jurassic-Cretaceous) of the Grajcarek Unit at Szczawnica-Zabaniszcze (Pieniny Klippen Belt, Carpathians, Poland). Geological Quarterly, 57, 3, 485-502.

Gedl P. \& Józsa Š., 2015. Early?-Middle Jurassic dinoflagellate cysts and foraminifera from the dark shale of the Pieniny Klippen Belt between Jarabina and Litmanová (Slovakia)age and palaeoenvironment. Annales Societatis Geologorum Poloniae, 85, 91-122.

Gedl P., Plašienka D., Schlögl J., Józsa Š. \& Madzin J., 2012. New occurrences of the Szlachtowa Formation in the surroundings of Jarabina village (Pieniny Klippen Belt, Eastern Slovakia). [in:] Józsa Š., Reháková D. \& Vojtko R. (eds.), Environmental, Structural and Stratigraphical Evolution of the Western Carpathians, 8th Conference, December $6^{\text {th }}-7^{\text {th }}$ 2012, Bratislava, Abstract Book, Comenius University, Bratislava, 9.

Golonka J. \& Rączkowski W., 1984. Objaśnienia do Szczegółowej mapy geologicznej Polski, skala 1: 50 000. Arkusz Piwniczna. Wydawnictwa Geologiczne, Warszawa.

Guterch A. \& Grad M., 2006. Lithospheric structure of the TESZ in Poland based on modern seismic experiments. Geological Quarterly, 50, 23-32.

Head M.J. \& Norris G., 1989. Palynology and dinocyst stratigraphy of the Eocene and Oligocene in ODP Leg 105, Hole 647A, Labrador Sea. [in:] Proceedings of the Ocean Drilling Program, Scientific Results, 105, College Station, Texas, 515-550.
Horwitz L., 1963. Budowa geologiczna Pienin: Ludwik Horwitz: przygot. do dr. i opatrzył przypisami Krzysztof Birkenmajer. Prace - Instytut Geologiczny, 38, Wydawnictwo Geologiczne, Warszawa.

Hudson W., Hart M.B., Sidorczuk M. \& Wierzbowski A., 2005. Jurassic planktonic foraminifera from Pieniny Klippen Belt and their taxonomie and phylogenetic importance (Carpathians, southern Poland). Volumina Jurassica, 3, 3, 1-10.

Iakovleva A.I., Brinkhuis H. \& Cavagnetto C., 2001. Late Palaoecene-Early Eocene dinoflagellate cysts from the Turgay Strait, Kazakhstan; correlations across ancient seaways. Palaoegeography, Palaeoclimatology, Palaeoecology, 172, 243-268.

Jacko S. \& Janočko J., 2000. Kinematic evolution of the Central-Carpathian Paleogene Basin in the Spišská Magura region(Slovakia).Slovak Geological Magazine, 6, 409-418.

Jurewicz E., 1994. Analiza strukturalna pienińskiego pasa skałkowego okolic Jaworek [Structural analysis of the Pieniny Klippen Belt at Jaworki, Carpathians, Poland]. Studia Geologica Polonica, 106, 7-87.

Jurewicz E., 1997. The contact between the Pieniny Klippen Belt and Magura Unit (the Małe Pieniny Mts.). Geological Quarterly, 41, 315-326.

Jurewicz E., 2005. Geodynamic evolution of the Tatra Mts. and the Pieniny Klippen Belt (Western Carpathians): problems and comments. Acta Geologica Polonica, 55, 295-338.

Jurewicz E., 2018. The Šariš Transitional Zone, revealing interactions between Pieniny Klippen Belt, Outer Carpathians and European platform. Swiss Journal of Geosciences. DOI: 10.1007/s00015-017-0297-9.

Jurewicz E. \& Nejbert K., 2005. Geotectonic position of the so-called "Pieniny Mts. andesites". [in:] Michalik M. (red.), VI Meeting of the Mineralogical Society of Poland: extended abstracts: Krościenko, 29 September - 2 October 2005, Prace Specjalne - Polskie Towarzystwo Mineralogiczne, 25, Mineralogical Society of Poland, Kraków, 179-183.

Jurewicz E., Hercman H. \& Nejbert K., 2007. Flowstone-like calcite in the andesite of Jarmuta Mt. - dating the Holocene tectonic activity in the vicinity of Szczawnica Magura Nappe, Outer Carpathians, Poland. Acta Geologica Polonica, 57, 187-204.

Krobicki M. \& Wierzbowski A., 2004. Pozycja stratygraficzna i paleogeograficzne znaczenie bajoskich wapieni krynoidowych $\mathrm{w}$ ewolucji pienińskiego basenu skałkowego [Stratigraphic position of the Bajocian crinoidal limestones and their palaeogeographic significance in evolution of the Pieniny Klippen Basin]. Volumina Jurassica, 2, 2, 69-82.

Krobicki \& Golonka 2008. Geological history of the Pieniny Klippen Belt and Middle Jurassic black shales as one of the oldest deposits of this region - stratigraphical position and palaeoenvironmental significance. Geoturysty$k a, 2$ (13), 3-18.

Książkiewicz M., 1972. The tectonics of the Carpathians. [in:] Pożaryski W. (ed.), Geology of Poland. Vol. 4: Tectonics, Wydawnictwa Geologiczne, Warszawa, 476-618.

Leśniak P., Sakai H., Ishibashi J. \& Wakita H., 1997. Mantle helium signal in the West Carpathians, Poland. Geochemical Journal, 31, 383-394. 
Mišík M., 1997. The Slovak part of the Pieniny Klippen Belt after the pioneering works of D. Andrusov. Geologica Carpathica, 48, 209-220.

Mohamed O. \& Wagreich M., 2013. Organic-walled dinoflagellate cyst biostratigraphy of the Well Höflein 6 in the Cretaceous-Paleogene Rhenodanubian Flysch Zone (Vienna Basin, Austria). Geologica Carpathica, 64, 3, 209-230.

Mohamed O., Piller W.E. \& Egger H., 2012. The dinocyst record across the Cretaceous-Palaeogene boundary of a bathyal midlatitude Tethyan setting: Gosau Group, Gams Basin, Austria. Cretaceous Research, 35, 143-168.

Nejbert K., Jurewicz E. \& Macdonald R., 2012. Potassium-rich rocks in the Western Outer Carpathians: magmagenesis in transitional zone between European Plate and the Carpathian-Pannonian regions. Lithos, 146-147, $34-47$.

Obermajer M., 1986. Microfacies and age of the Pieniny Limestone Formation (Tithonian-Barremian) of the Grajcarek Unit, eastern part of the Pieniny Klippen Belt, Carpathians. Przeglad Geologiczny, 34, 6, 317-323.

Oszczypko N., 2006. Late Jurassic-Miocene evolution of the Outer Carpathian fold-and thrust belt and its foredeep basin (Western Carpathians, Poland). Geological Quarterly, 50, 169-194.

Oszczypko N. \& Oszczypko-Clowes M., 2014. Geological structure and evolution of the Pieniny Klippen Belt to the east of the Dunajec River - a new approach (Poland). Geological Quarterly, 58, 737-758.

Oszczypko N., Malata E., Švábenická L., Golonka J. \& Marko F., 2004. Jurassic-Cretaceous controversies in the Western Carpathian flysch - the "black flysch" case study. Cretaceous Research, 25, 89-113.

Oszczypko N., Oszczypko-Clowes M., Golonka J. \& Marko F., 2005. Oligocene-Lower Miocene sequences of the Pieniny Klippen Belt and adjacent Magura Nappe between Jarabina and the Poprad River (East Slovakia and South Poland): their tectonic position and palaeogeographic implications. Geological Quarterly, 49, 4, 379-402.

Oszczypko N., Olszewska B. \& Malata E., 2012. Cretaceous (Aptian/Albian-?Cenomanian) age of "black flysch"and adjacent deposits of the Grajcarek thrust-sheets in the Małe Pieniny Mts. (Pieniny Klippen Belt, Polish Outer Carpathians). Geological Quarterly, 56, 411-440. DOI: http://dx.doi.org/10.7306/gq.1031.

Pin C., Bouvier A. \& Aleksandrowski P., 2004. Major trace element and Sr-Nd Isotope Data on Neogene andesitic rocks from the Pieniny Klippen Belt (southern Poland) and geodynamic inferences. Mineralogical Society of Poland - Special Paper, 24, 323-328.

Plašienka D., 2012. Early stages of structural evolution of the Carpathian Klippen Belt (Slovakian Pieniny sector). Mineralia Slovaca, 44, 1-16.

Plašienka D., Soták J., Jamrichová M., Halásová E., Pivko D., Józsa Š., Madzin J. \& Mikuš V., 2012. Structure and evolution of the Pieniny Klippen Belt demonstrated along a section between Jarabina and Litmanová villages in the Eastern Slovakia. Mineralia Slovaca, 44, 17-38.

Plašienka D., Soták J., Aubrecht R. \& Michalík J., 2017. Discussion of 'Olistostromes of the Pieniny Klippen Belt, Northern Carpathians. Geological Magazine, 54, 1, 187-192. DOI: 10.1017/S0016756815000813.
Powell A.J., Brinkhuis H. \& Bujak J.P., 1996. Upper Paleocene-Lower Eocene dinoflagellate cyst sequence biostratigraphy of southeast England. [in:] O’Brien Knox R.W., Corfield R.M., Dunay R.E. (eds.), Correlation of the Early Paleogene in Northwest Europe, Geological Society Special Publications, 101, Geological Society, London, 145-183.

Pożaryski W., 1991. The strike-slip terrane model for the North German-Polish Caledonides. Publications of the Institute of Geophysics, Polish Academy of Sciences, A-19, 236, 3-15.

Pszczółkowski A., 2015. Aptian age of the „spotted limestone" (Pieniny Limestone Formation) in the Grajcarek Stream (Pieniny Klippen Belt, Poland). Annales Societatis Geologorum Poloniae, 85: 21-42.

Segit T., 2010. Stratygrafia, zróżnicowanie facjalne i środowisko sedymentacji aalenu $i$ niższego bajosu pienińskiego basenu skałkowego $w$ wybranych profilach Polski i Słowacji. Wydział Geologii, Uniwersytet Warszaqwski [Ph.D. thesis, unpublished].

Segit T., Matyja B.A. \& Wierzbowski A., 2015. The Middle Jurassic succession in the central sector of the Pieniny Klippen Belt (Sprzycne Creek); implication for the timing of the Czorsztyn Ridge development. Geologica Carpathica, 66, 285-302.

Sikora W., 1962. New data on the geology of the Pieniny Klippen Belt. Bulletin of the Polish Academy of Sciences. Earth Sciences, 10, 203-211.

Sikora W., 1971. Stop 9 - Profil środkowego odcinka potoku Sprzycne. [in:] Przewodnik XLIII zjazdu Polskiego Towarzystwa Geologicznego, Kraków 2-14 września 1971. Wyd. Geologiczne, Warszawa, 241-243.

Slimani H., Louwye S. \& Toufiq A., 2010. Dinoflagellate cysts from the Cretaceous-Paleogene boundary at Ouled Haddou, southeastern Rif, Morocco: biostratigraphy, paleoenvironments and paleobiogeography. Palynology, $34,1,90-124$.

Soliman O., 2012. Oligocene dinoflagellate cysts from the North Alpine Foreland Basin: new data from the Eggerding Formation (Austria). Geologica Carpathica, 63, 49-70.

Storey M., Duncan R.A. \& Swisher C.C., 2007. Paleocene-Eocene Thermal Maximum and the Opening of the Northeast Atlantic. Science, 27, 316, 5824, 587-589.

Tyszka J., 1995. Mid-Jurassic palaeoenvironment and benthic communities in the Pieniny Klippen Belt and the Magura basins, Pieniny Klippen Belt, Poland. Institute of Geological Sciences, Polish Academy of Sciences, Kraków [Ph.D. thesis, unpublished].

Țabără D., Slimani H., Carmen S.M. \& Chirac M., 2017. Integrated biostratigraphy and palaeoenvironmental interpretation of the Upper Cretaceous to Paleocene succession in the northern Moldavidian Domain (Eastern Carpathians, Romania). Cretaceous Research, 77, 102-123.

Waśkowska A. \& Golonka J., 2016. Wodospad Zaskalnik ważna strefa kontaktu jednostek litostratygraficzych płaszczowiny magurskiej w Beskidzie Sądeckim [Zaskalnik Waterfall - an important lithostratigraphic contact zone of the Magura Nappe in the Beskid Sądecki Mts.] Chrońmy Przyrodę Ojczysta, 72, 4, 254-268. 
Wierzbowski A., 1994. Late Middle Jurassic to earliest Cretaceous stratigraphy and microfacies of the Czorsztyn Succession in the Spisz area, Pieniny Klippen Belt, Poland. Acta Geologica Polonica, 44, 223-249.

Wierzbowski A., Aubrecht R., Krobicki M., Matyja B.A. \& Schlögl J., 2004. Stratigraphy and palaeogeographic position of the Jurassic Czertezik Succession, Pieniny Klippen Belt (Western Carpathians) of Poland and Eastern Slovakia. Annales Societatis Geologorum Poloniae, 74, 237-256.

Young J.R., Bown P.R., Lees J.A. (eds.). Nannotax3 website. International Nannoplankton Association 20 Jan.
2018, [on-line:] http://ina.tmsoc.org/Nannotax3 [access: 20.01.2018].

Zuchiewicz W. \& Oszczypko N., 2008. Topography of the Magura floor thrust and morphotectonics of the Outer West Carpathians in Poland. Annales Societatis Geologorum Poloniae, 78, 135-148.

Żaba J., 1996. Późnokarbońska aktywność przesuwcza strefy granicznej bloków górnośląskiego i małopolskiego [Late Carboniferous strike-slip activity at the boundary zone of Upper Silesia and Małopolska Blocks]. Przeglad Geologiczny, 44, 2, 173-180. 